\title{
The Impact of Task-based Approach on Vocabulary Learning in ESP Courses
}

\author{
Abdullah Sarani ${ }^{1} \&$ Leila Farzaneh Sahebi ${ }^{1}$ \\ ${ }^{1}$ English language and literature department, University of Sistan \& Baluchestan, Zahedan, Iran \\ Correspondence: Leila Farzaneh Sahebi, English language and literature department, University of Sistan \& \\ Baluchestan, Zahedan, Iran. E-mail: Leila.farzaneh.s@gmail.com
}

\author{
Received: February 24, 2012 Accepted: July 18, 2012 Online Published: August 23, 2012 \\ doi:10.5539/elt.v5n10p118 URL: http://dx.doi.org/10.5539/elt.v5n10p118
}

\begin{abstract}
This study investigates the teaching of vocabulary in ESP courses within the paradigm of task-based language teaching, concentrating on Persian literature students at Birjand University in Iran. Two homogenous groups of students who were taking their ESP courses participated in the study as a control and an experimental group. A teacher-made test of technical vocabulary knowledge was administered as the pre-test. Vocabularies in the control group were taught using a traditional approach, whereas in the experimental group, technical vocabularies were taught on the basis of task-based approach. At the end of the semester, a post-test was given to the students to determine the influence of the treatment on the experimental group. Data analysis showed that the task-based approach was more effective in teaching technical vocabularies compared to the traditional one. Furthermore, the results showed that in the experimental group the male learners outperformed the female learners.
\end{abstract}

Keywords: task, task-based language teaching, traditional approach, ESP

\section{Introduction}

The early application of task-based approach within a communicative framework for language teaching is the Prabhu's Bangalore project. In this approach learners are presented with a task or problem to solve and do not concentrate on language features during performance. These tasks are meaning-focused and have a non-linguistic outcome (Ellis, 2003). This new trend in English Language Teaching seems to be best applied to English for Specific Purpose (ESP) courses which has emphasized the need for teaching specialized vocabulary ever since its beginnings, back in the 1960 's (Nito, 2004). However teaching specialized vocabulary to ESP learners has also been a concern throughout the history of ESP and language teaching. Despite the fact that through previous researches many theoretical claims have been made about using tasks in teaching vocabulary to ESP learners, nothing has been done practically in Iran an EFL context. Therefore, the present study is an attempt to investigate whether task-based approach is appropriate for vocabulary development in an ESP course.

\section{Statement of Problem}

Over the years, different approaches, methods and procedures, have been employed to help learners learn second language. In one period considerable attention was paid to teaching and teacher-oriented classes. Because the emphasis was on grammatical and paid to phonological structures, the vocabulary needed to be relatively simple, with new words introduced only as they were needed to make the drills possible. The belief was that vocabulary would take care of itself once the students learnt the grammatical structures (Zandmoghadam, 2007). Most of ESP students in Iran are well aware of the importance of vocabulary in studying a foreign language; they are well aware of their need to enrich their vocabulary as well as to improve their communicative competence but in ESP courses in Iran at university level, despite new methods and approaches, most of the techniques teachers use on teaching vocabulary are still traditional; the teacher focuses on the translation of technical text and there is no real interaction among students.

Therefore, the present study determines whether teaching to ESP student through task-based approach can be influential and practically useful in ESP vocabulary improvement.

\section{Review of Literature}

\subsection{Task-based Language Teaching}

According to Richards and Rodgers (2001), "task-based language teaching refers to an approach based on the 
use of tasks as the core unit of planning and instruction in language teaching" (p. 223). Nunan (2004) believes that "task is an important element in syllabus design, classroom teaching and learner assessment" (p. 1). Ellis (2003) maintains that "tasks hold a central place in current second language acquisition (SLA) research and language pedagogy" (p. 1). According to Willis (1996), tasks are always activities where the target language is used by the learner for a communication purpose in order to achieve an outcome (p. 23). Richards and Rodgers (2001) offer some assumptions which are believed to underlie TBLT. As far as the theory of language is concerned, "language is primarily a means of making meaning" that is, what is important in language use is meaning. In fact, Skehan (1998), in his definition referred to this point too. "Multiple models of language inform task-based learning". Richards and Rodgers (2001) believe that TBLT draws on functional, interactional and, in some cases, structural models of language. Skehan (1998) believes that when we deal with task complexity, we have to consider the structural model too. "Lexical units are central in language use and language learning", and "conversation" is the central focus of language and the keystone of language acquisition".

When it comes to the theory of learning, Richards and Rodgers (2001), propose that "tasks provide both the input and the output processing necessary for language acquisition". "Task activity and achievement are motivational" (p. 228). Motivation is a need for language learning. Brown (2000) argues that "it is easy in second language learning to claim that a learner will be successful with the proper motivation" (p. 160).

Lots of procedures and stages have been devised so far, but Ellis (2003) believes that they all have in common three principal phases: pre-task, during task, and post-task. In pre-task phase the overall purpose of this phase is to prepare the learners for the next phase, that is, students should get prepared for completing the task. In fact, the pre-task phase has two basic functions: 1) to introduce and create interest in doing a task on the chosen topic, and 2) to activate topic-related words, phrases and target sentences that will be useful in carrying out the task and in the real world communication. A third, optional function is the inclusion of an enabling task to help students communicate as smoothly as possible during the task cycle (Rooney, 2000). In the "during task" phase students work in pairs or groups although this is dependent on the type of activity, and they use whatever linguistic resources they possess to achieve the goals of the task. The post-task phase in the framework, the language focus, provides an opportunity for form-focused work. Having completed the task, the students prepare either a written or oral report to present to the class. In this phase, some of the specific features of the language, which occurred naturally during the task, are identified and analyzed (Rooney, 2000). Finally, Willis's phases of applying tasks in a task-based language teaching can be summarized as in Figure 1.

\subsection{English for Specific Purposes}

The study of Language for Specific Purposes (LSP) has a long and valid history (Streven, 1977; cited in Johns \& Dudly-Evans, 1998). Specially today since the focus of research is upon English, English for specific purposes has gained ascendency in different fields (Johns \& Dudley-Evans, 1998). "ESP has been referred to as applied ELT as the content and aim of any course is determined by needs of a specific group of learners" (Dudly-Evans, 1998). Howatt (1984) introduces ESP as an innovative activity in the domain of language teaching. Strevans (1988; cited in Dudly-Evans and St John, 1998, p. 3) defines ESP in terms of four absolute characteristics and two variable characteristics. The absolute characteristics are that ESP consists of English Language Teaching which is

- $\quad$ designed to meet the specified needs of the learner;

- related in content ( that is in its themes and topics) to particular disciplines, occupations and activities;

- centered on language appropriate to those activities in syntax, lexis, discourse, semantic and so on, and analysis of the discourse;

- $\quad$ in contrast with 'general English'.

And the variable characteristics are that ESP

- $\quad$ may be restricted as to the learning skills to be learned (for example reading only);

- may not be taught according to any pre-ordained methodology

Later Dudly-Evans and St John (1998, p. 4) modified Strevens's definition in the following way:

Absolute characteristics:

- $\quad$ ESP is designed to meet specific the needs of the learners;

- $\quad$ ESP makes use of underlying methodology and activities of the discipline it serves; 
- ESP is centered on the language appropriate to these activities in terms of grammar, lexis, register, study skills, discourse and genre.

Variable characteristics:

- $\quad$ ESP may be related to or designed for specific disciplines;

- ESP may use, in specific teaching situations, a different methodology from that of General English;

- $\quad$ ESP is likely to be designed for intermediate or advanced students;

- Most ESP courses assume some basic knowledge of the language systems.

Robinson (1991) believes that ESP is a major activity around the world today. Huchinson and Waters (1993), make the point clear: ESP is not a matter of teaching specialized varieties of English, nor is just matter of science words and grammar for scientists. It is also not different in kind from any other form of language teaching as far as principles of effective and efficient learning are concerned (p. 18).

\subsection{Vocabulary}

Richards and Renandya (2002) assume that "vocabulary is a core component of language proficiency and provides much of the basis for how well learners speak, listen, read, and write" (Richards \& Renandya, 2002, p. 255). In terms of teaching technical vocabulary in ESP, it is most important to make a distinction between two types of vocabulary: technical and semi-technical. Dudly-Evans and St John (1998, p. 83) suggest two broad areas related to technical vocabulary.

1. Vocabulary that is used in general language but has a higher frequency of occurrence in specific and technical description and discussion.

2. Vocabulary that has specialized and restricted meanings in certain disciplines and which may vary in meaning across disciplines.

According to Hutchinson and Waters (1987), ESP should be seen as an approach to language teaching which is directed by specific and apparent reasons for learning. Their specific and apparent reason for learning English is for academic purposes and their academic study will involve specialized areas across different discipline in physical sciences as well as in social sciences. The aim of their vocabulary acquisition is surely academic vocabulary. A rationale behind this is that learners will do academic study in English must focus on academic vocabulary which is variously known as a general useful scientific vocabulary and semi-technical vocabulary because they need to exhibit a wide range of academic skills like reading about research papers in their own fields, listening to teachers speak about their work, writing academic papers and presenting oral or written evaluations of methods or results in many cases(Barber, $1962 \&$ Farrel, 1990).

Cubillo and Brenes (2009) examined task-based instruction in an ESP course in the computer center at the University of Costa Rica. This study presented the advantages of using Task -based learning to help learners from the computer center at the university of Costa Rica infer the rule of the superlative form of adjectives in English. It is important to mention that the methodology based on tasks help learners pay more attention or concentrate more on meaning. Task-based language learning is an approach in which learners concentrate more on meaning than on form. By doing this, students perform different communicative tasks, which happen to be more meaningful because they are close to the learners' reality, instead of doing form-based discrete exercises, which are usually decontextualized and meaningless because they do not see a reason to do them. Cubillo concluded that it is important to point out that implementing the TBL methodology in an ESP context is a challenging task for language teachers. As Brown (1994) pointed out teachers should take advantage of different approaches and techniques and combine them to help learners improve their skills. Subsequently, by implementing task-based instruction, learners as well as teachers will certainly benefit from a different approach to language pedagogy because it is more motivating, challenging, innovative, appealing and meaningful to students than other traditional grammar-translation based approaches.

If the curriculum is learner - centered, i.e. Task-Based Language Teaching as it has shown that learners have the greatest role in a learning process. Learners' cooperative activity and speaking in groups while performing tasks have significant role. In this regard gender is one of the effective factors in language learning. Although many studies revealed that there is no significant difference between male and female in language learning as a whole, like (Yarahadi, 2011; Kashefian \& Maroof, 2010) but many others had different results and rejected the aforementioned statement. For example Zare (2010) investigated how the use of language learning strategies varies according to gender and revealed that in Iran female EFL learners prevailed over males in the use of strategies. So the second attempt of this study is to demonstrate whether gender difference has any considerable 
effect on vocabulary learning in ESP courses in Iran or not.

This study was primarily designed to investigate the effect of task-based teaching of technical vocabulary on Iranian ESP learners. It also tried to find out whether there is any difference between male and female learners in learning vocabulary through task-based approach. Regarding the objectives of the study the following research questions were proposed:

Q1. Will there be differences in the performance of students taught ESP vocabulary by a task-based approach and that of students taught by a traditional method?

Q2. Is there any significant difference between the performance of the male and the female learners taught vocabulary in ESP courses by a task-based approach during a semester?

\section{Method}

\subsection{Participants}

A sample of 60 BA students of Persian literature aging from 18-25 in Birjand University of Humanities participated in this study. After screening the participants by the Nation's vocabulary test, $50(\mathrm{~N}=50)$ of them were selected and were assigned randomly to two groups of 25 , namely a control group and an experimental group. The two classes included 10 male and 15 female students. The participants came from various socioeconomic backgrounds and different cities of Iran.

\subsection{Instruments}

\subsubsection{Nation's (2007) Vocabulary Pre-test}

In order to achieve maximum possible homogeneity among the subjects regarding their general vocabulary, a Nation's vocabulary test was administered at the beginning of the study. The reliability of this test was calculated by Cronbach Alpha Formula which was 0.95 . The test included 30 multiple-choice items. The grades were calculated out of 30 .

\subsubsection{Teacher-made Technical Vocabulary Pre-test}

After the subjects were homogenized regarding their general vocabulary knowledge, another the teacher-made technical vocabulary test with 30 multiple-choice items was administered to test the ESP learners' ability regarding their technical vocabulary knowledge. To standardize the test, a pilot study was conducted to calculate the reliability of the technical vocabulary test. The reliability of the test was calculated by Kurder-Richardson formula and it was 0.82 .

\subsubsection{Teacher-made Technical Vocabulary Post-test}

In order to see whether the task-based instruction of vocabulary had any significant effects on ESP learners' technical vocabulary knowledge, the same technical vocabulary test with $30 \mathrm{mc}$ items was administered as the post-test after treatment.

\subsection{Procedure}

The study was conducted at the beginning of the semester. After homogenizing participants regarding their general vocabulary competence, the researcher divided them in to two groups namely a control and an experimental group. After that, the teacher-made pre-test regarding their technical vocabulary knowledge was assigned in each group. The researcher applied two different approaches to teach technical vocabularies to the participants in the study. The participants in the control group were required to study the texts, translate them and answer some non-task-based comprehension questions, i.e. they were taught technical vocabulary based on the traditional method. For the experimental group the same passages with some task-based exercises which fit a task-based framework were used. In fact, the class time was divided into three phases: pre-task, task cycle and post-task (see appendix A).

In pre-task phase the researcher tried to activate the ESL learner's schemata related to the text with new technical vocabularies to motivate them to read. In the during task phase, the students were engaged in completing different kinds of tasks, and in the post-task phase, they gave a report, repeated the tasks and even dealt with language focus tasks. In fact the classes were held one session a week for one hour and a half. After thirteen weeks of instruction, the teacher-made technical test was given to find out the probable differences between the performances of the two groups.

\subsection{Data Analysis}

After collecting data, it was processed by SPSS program. In the case of the first question, first of all descriptive 
statistics paired sample $t$-test was run to examine whether there was significant difference in vocabulary knowledge of learners in the experimental and the control group. An independent sample $t$-test was run to compare the means of two groups in post-test. To find out the probable differences in vocabulary learning between male and female in the experimental group, in fact, for the second research question, first of all descriptive statistics were computed and to see whether the mean difference is significant or not the researcher ran another independent sample $t$-test on post-test of the experimental group.

\section{Result \& Discussion}

\subsection{Control Group}

To answer the first question concerning the effect of task-based language teaching approach on vocabulary learning of ESP students, Descriptive statistics and a set of paired and independent $t$-test was used.

The result of table 1 shows that there is not considerable improvement in the control group.

Table 1. Descriptive statistics of control group pretest, post-test

\begin{tabular}{ccccccc}
\hline & N & Max & Min & Mean & Std.deviation & Std. error mean \\
\hline Control pretest & 25 & 27 & 11 & 17.88 & 4.87 & .975 \\
\hline Control post-test & 25 & 25 & 13 & 18.04 & 4.026 & .805 \\
\hline
\end{tabular}

To make sure whether there is any significant difference between the mean scores of the pre-test and the post-test in the control group, the researcher ran a paired sample $t$-test.

Table 2 demonstrates the computations of $t$ value. Results showed that the $t$-value with its 24 degrees of freedom (df) was .267. Since the $t$-observed (-.267) was less than $t$-critical (2.064), at 0.05 level of significance, therefore it can be concluded that the difference between the mean of the pre-test and that of the post-test in control group was not significant. Therefore, based on this analysis, their vocabulary competence was not improved noticeably.

Table 2. Paired sample t-test, the control group pretest mean compare with the control group post-test mean

\begin{tabular}{|c|c|c|c|c|c|c|c|c|}
\hline & \multicolumn{5}{|c|}{ Paired difference } & \multirow[b]{3}{*}{$\mathrm{t}$} & \multirow[b]{3}{*}{$\mathrm{df}$} & \multirow[b]{3}{*}{ Sig.(2-tailed) } \\
\hline & \multirow[b]{2}{*}{ Mean } & \multirow[b]{2}{*}{ Std.deviation } & \multirow{2}{*}{$\begin{array}{l}\text { Std. } \\
\text { error } \\
\text { mean }\end{array}$} & \multicolumn{2}{|c|}{$\begin{array}{l}95 \% \text { confidence interval of } \\
\text { the difference }\end{array}$} & & & \\
\hline & & & & Lower & Upper & & & \\
\hline Pair 1 & & & & & & & & \\
\hline pretest-post-test & -.160 & 2.996 & .599 & -1.397 & 1.077 & -.267 & 24 & .792 \\
\hline
\end{tabular}

\subsection{Experimental Group}

Table 3 summarizes the descriptive statistics of both pre-test and post-test of the experimental group.

Table 3. Descriptive statistics of experimental group pretest, post-test

\begin{tabular}{lcccccc}
\hline & $\mathrm{N}$ & Max & Min & Mean & Std.deviation & Std. error mean \\
\hline Experimental pretest & 25 & 28 & 11 & 18.52 & 5.347 & 1.068 \\
\hline Experimental post-test & 25 & 27 & 20 & 24 & 2.693 & .539 \\
\hline
\end{tabular}

Concerning participants in the experimental group, the mean of their scores on the pre-test was 18.52 the SD was (5.347). After receiving task-based instruction in technical vocabulary, their mean scores on the pre-test was increased to 24.00, with the standard deviation (SD) of 2.693.

In order to examine whether the difference between the pre-test and the post-test of experimental group was statistically significant or not, paired sample $t$-test was run. 
Table 4. Paired sample test: the experimental group pretest mean compare with the experimental group post-test mean

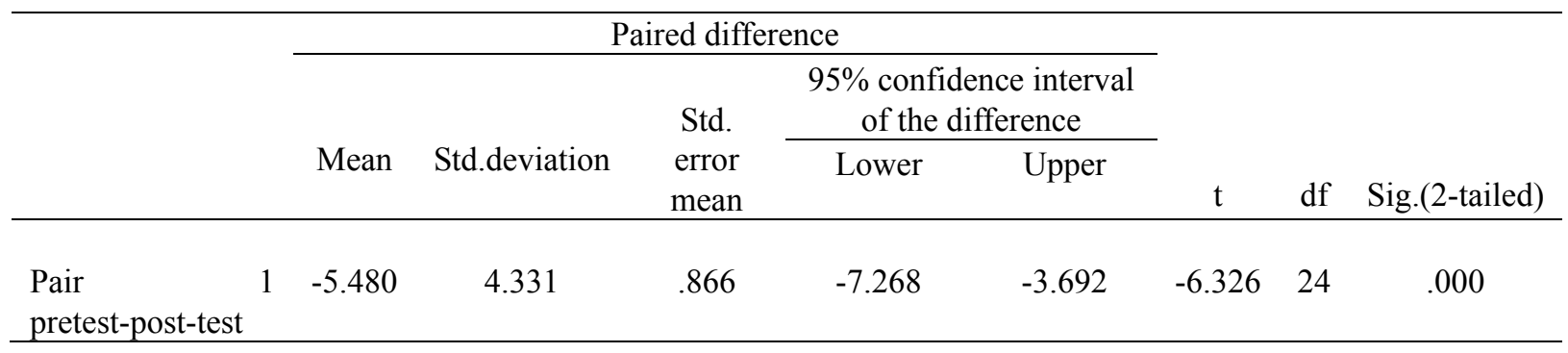

As Table 4 displays, the $t$-value with its 24 degrees of freedom (df) was -6.326. In fact, the observed (6.326) was more than $t$-critical (2.064), at 0.05 level of significance $(\mathrm{p}<.05)$. As a result, a significant difference was detected between learners' mean scores in the pre-test and the post-test within the experimental group.

However, to be able to answer the first research question, the researcher compared the mean scores of the post-tests of both control and experimental groups and ran an independent-sample $t$-test.

Table 5. Independent sample t-test, control group post-test vs. Experimental group post-test

\begin{tabular}{|c|c|c|c|c|c|c|c|c|c|}
\hline & $\begin{array}{l}\text { Leven } \\
\text { for eq } \\
\text { varian }\end{array}$ & $\begin{array}{r}\text { test } \\
\text { lity of } \\
\end{array}$ & \multicolumn{7}{|c|}{ t-test for equality of means } \\
\hline & \multirow[t]{2}{*}{$\mathrm{F}$} & \multirow[t]{2}{*}{ Sig } & \multirow[t]{2}{*}{$\mathrm{t}$} & \multirow[t]{2}{*}{ Df } & \multirow[t]{2}{*}{ Sig.(2-tailed) } & \multirow{2}{*}{$\begin{array}{c}\text { Mean } \\
\text { difference }\end{array}$} & \multirow[t]{2}{*}{$\begin{array}{l}\text { Std. error } \\
\text { difference }\end{array}$} & \multicolumn{2}{|c|}{$\begin{array}{l}95 \% \text { confidence } \\
\text { interval of the } \\
\text { difference }\end{array}$} \\
\hline & & & & & & & & Lower & Upper \\
\hline $\begin{array}{l}\text { Posttet Equal } \\
\text { variances } \\
\text { assumed }\end{array}$ & 5,461 & .024 & $-6,153$ & 48 & .000 & $-5,960$ & .969 & $-7,908$ & $-4,012$ \\
\hline $\begin{array}{l}\text { Equal variances } \\
\text { not assumed }\end{array}$ & & & $-6,153$ & 41,892 & .000 & $-5,960$ & .969 & $-7,915$ & $-4,005$ \\
\hline
\end{tabular}

As it is demonstrated in the Table 5 the $t$-observed with its 48 degrees of freedom, was -6.153 . In fact this $t$ is larger than $t$-critical at 0.05 level of significance $(p<.05)$ which is $(2.011)$. It means teaching technical vocabulary through task-based approach has a significant effect on ESP learners' technical vocabulary improvement.

In order to answer the second research, the researcher's attempt was to compare the performance of males and females on the post-test in the experimental group. Table 6 below shows the descriptive statistics of males and females performance in the experimental group. As Table 6 demonstrates in this group the male learners performed better than the female learners.

Table 6. Descriptive statistics of male and female performance in experimental group

\begin{tabular}{ccccc}
\hline Gender & $\mathrm{N}$ & Mean & Std.Deviation & Std. error mean \\
\hline Female & 15 & 22.80 & 2.731 & .705 \\
\hline Male & 10 & 25.80 & 1.317 & .416
\end{tabular}

In order to see if this difference is meaningful or not the researcher ran another independent $t$-test on the post-test in task-based class. Results are given in Table 7. 
Table 7. Independent Samples t- test: female and male difference in vocabulary learning

\begin{tabular}{|c|c|c|c|c|c|c|c|c|c|}
\hline & $\begin{array}{l}\text { Levene } \\
\text { for equ } \\
\text { varianc }\end{array}$ & $\begin{array}{l}\text { test } \\
\text { lity of }\end{array}$ & \multicolumn{7}{|c|}{ t-test for equality of means } \\
\hline & \multirow[t]{2}{*}{$\mathrm{F}$} & \multirow[t]{2}{*}{ Sig } & \multirow[t]{2}{*}{$\mathrm{t}$} & \multirow[t]{2}{*}{ Df } & \multirow[t]{2}{*}{$\begin{array}{l}\text { Sig.(2- } \\
\text { tailed) }\end{array}$} & \multirow{2}{*}{$\begin{array}{c}\text { Mean } \\
\text { difference }\end{array}$} & \multirow[t]{2}{*}{$\begin{array}{l}\text { Std. error } \\
\text { difference }\end{array}$} & \multicolumn{2}{|c|}{$\begin{array}{l}95 \% \text { confidence } \\
\text { interval of the } \\
\text { difference }\end{array}$} \\
\hline & & & & & & & & Lower & Upper \\
\hline $\begin{array}{l}\text { Posttest Equal } \\
\text { variances } \\
\text { Assumed }\end{array}$ & 5.858 & .024 & -3.217 & 23 & .004 & 3.000 & .933 & -4.929 & -1.071 \\
\hline $\begin{array}{c}\text { Equal variances } \\
\text { not assumed }\end{array}$ & & & -3.664 & 21.415 & .001 & 3.000 & .819 & -4.701 & -1.299 \\
\hline
\end{tabular}

As Table 7 depicts, the $t$-value with its 21 degrees of freedom was -3.664. In fact the $t$-observed (-3.664) was more than $t$-critical (2.80), at 0.05 level of significance. Therefore, the significance of differences between male and female was proved. That means male learners outperformed female learners.

\section{Discussion}

One of the major aims of this study was to determine if the application of task-based has any impact on vocabulary learning of ESP students. The reported findings show that there will be significant difference at .05 level. That is the participants' performance in the task-based class was remarkably better than that of traditional class. Apparently, the significant improvement regarding the vocabulary learning ability of the participants in the experimental group must have originated from the type of instruction they had been exposed to during the time (13 sessions) that the experiment was conducted. Another factor that may affect learners' performance is the nature of the task that may be stimulating. Richards and Rogers (2001, p. 229) assert that task activity and task achievement, as a characteristic for task-based instruction, are motivational. Brown (2000) goes on to state "it is easy to assume that success in any task is due simply to the fact that someone is motivated" (p. 160). Generally, TBI has the potential to bring about moderate to large vocabulary gains. It is not unlikely that the characteristics of tasks, authentic materials, learner-centered communication, negotiation of meaning, integration of new and existing knowledge, and a meaningful non-linguistic outcome can foster vocabulary acquisition in the same manner they foster the acquisition of other language features.

The second objective of the present study was to discover if there is a difference between males and females in learning vocabulary in the class which was conducted based on the task-based approach. The findings revealed that males notably performed better than females in the experimental group.

Psychologists have found there are significant differences in cognitive performance of males and females. Batters (1986) found that "first, females spent more time on attentive activities than males. Attentive activities included listening to the teacher, to the tape, to other classmates, observing and reading (p. 78). Second, males were more dominant in oral and participatory activities, such as speaking to the teacher and to other pupils in the foreign or native language, taking part in group work or demonstration and showing spontaneity" (Batters, 1986, p. 78). Gibbs (2001) reported the reasons for such inequalities in vocabulary learning. He argues that females are generally encouraged to be more passive. Consequently, they do not participate in class with as much ease and confidence as many of their male peers. Moreover, the conservative nature of culture, customs, and habits prevents females in Iran socializing and establishing relationships outside their immediate circles, which is a prerequisite for excelling in acquiring a foreign language within any communicatively oriented approach to language learning.

Similarly in this study the only significant difference between males and females was in their use of social strategies. Male students showed higher preference for these strategies than their female counterparts, which means they were more likely to interact, cooperate, and empathize with others. This, as explained previously, is probably due to disparity in social expectations and cultural background placed on both groups.

\section{Conclusion and Implication}

As it was observed those ESP learners who have been taught vocabulary through task-based language teaching outperformed those learners who have been taught vocabulary through traditional approach. So, the traditional approach, in this context is proved to be unsuccessful. The current study has provided further empirical evidence 
for the value of a task-based approach to second language learning. It shows that learner-learner interaction while performing tasks provided opportunities for the learners to talk about vocabularies and monitor the language they used.

TBLT is a meaning-centered methodology, according to Ellis (2003), such meaningfulness in TBLT provides an authentic, purposeful, and intentional background for comprehending and using language, and it is encouraging for the EFL learners. But in traditional method the focus is on translation and memorization of new vocabularies and students are not concerned with the context in which these technical vocabularies are used. One of the features which can be referred to as a reason for the outperformance of the TBLT class in comparison with the traditional class is the collaborative and interactive nature of the task-based approach where language use and language learning take place simultaneously.

The cooperative natures of planning and report stages help students get feedback from the members of a task group. Of course, the students in TBLT receive feedback from the teacher. However, in the traditional group the students work individually on the exercises, so they do not receive any feedback from their peers and the only authority for judging about accuracy of exercises is the teacher. Therefore, it can be claimed that the existence of such a feedback provides a more relaxing and less threatening condition for learning foreign language.

Regarding the second research question, first, in this group the male learners showed more interest and their participation was more than the females' participation in learning vocabulary by doing task. Second, females' shyness and lack of confidence in cooperative activities could act as an obstacle in learning and participation in the class.

This study emphasized on the effectiveness of the task-based approach on technical vocabulary learning of ESP students. In Iran EFL context, in which learners don't have much contact with native speakers of English, the focus of language teaching should be placed on changing the classroom practice from the traditional passive lecture to more active group learning so that learners can be more easily exposed to target language use. The findings of this research can have several implications in ESP, language teaching methodology, materials development and teacher-training programs As far as ESP is concerned, ESP learners can best benefit from task-based teaching of vocabulary. With regard to language teaching methodology, the findings of this study emphasizes the role of task-based approach in teaching vocabulary. In fact, everything turns around tasks and task completion in this approach. The three stages of applying tasks can be used to teach vocabulary and other language skills and sub skills to ESL and ESL learners too. Actually, it can be an alternative to the common PPP model. Concerning materials development, new textbooks must be designed for ESP learners. The books must be as communicative as possible. The books must pay equal attention to all four language skills and sub-skills especially vocabulary. They must be designed based on tasks.

\section{References}

Batters, J. (1986). Do boys really think languages are just girl-talk? Modern Languages, 67(2), 75-79.

Brown, H. D. (2000). Principle of language learning and teaching. New York: Pearson Education.

Choudhury, A. (2010). Teaching vocabulary in the ESL/EFL classroom: central pedagogical issues. MJAL Journal, 2(4), 306-316.

Cubillo, P., \& Brenes, C. (2009). Using task-based instruction in ESP course in the computer center at the University of Costa Rica. INIE Journal of Costa Rica University, 9(1), 1-25.

Dudley-Evans, T., \& St John, M. J. (1998). Developments in English for Specific Purposes. Cambridge: Cambridge University Press.

Ellis R. (2003). Task-based Language Teaching and Learning. Oxford, OUP.

Farrell, P. (1990). Vocabulary in ESP: a lexical analysis of the English of electronics and a study of semi-technical vocabulary CLCS Occasional. Journal of Trinity College, 10(3).

Gibbs, J. (2001). Tribes: A new way of learning and being together. Windsor, CA: Center Source Systems.

Howatt, A. (1984). A history of English language teaching. Oxford: Oxford University Press.

Kashefian, S., \& Maarof, N. (2010). A study of the use of language learning strategies among students in Iran. Malaysian Journal of ELT research, 6, 195-233.

Nito, R. (2004). Vocabulary \& ESP: Teaching Business Vocabulary. Retrieved $25^{\text {th }}$ October 2011, from http://www.scribd.com/doc/46984761/ESP

Nunan, D. (2004). Task-based language teaching. Cambridge University Press. 
http://dx.doi.org/10.1017/CBO9780511667336

Prabhu, N. S. (1987). Second language pedagogy. Oxford: Oxford University Press.

Richards, J. C., \& Rodgers, T. (2001). Approaches and methods in language teaching. Cambridge: Cambridge University Press. http://dx.doi.org/10.1017/CBO9780511667305

Richards, J. C., \& Renandya, W. A. (2002). Methodology in language teaching. Cambridge: Cambridge university press. http://dx.doi.org/10.1017/CBO9780511667190

Robison, P. C. (1991). ESP today: A practitioner's guide. UK: Prentice Hall International Ltd,

Willis, J. (1996). A framework for task-based learning. Harlow: Longman.

Skehan, P. (1998a). Task-based instruction. Annual Review of Applied Linguistics, 18, 268-286. http://dx.doi.org/10.1017/S0267190500003585

Yarahmadi, M. (2011). Gender differences views on problem-solving reading strategies in L2 a case study of Iranian EFL learners. Journal of basic and applied scientific research, 1(12), 2633-2634.

Zare, P. (2010). An investigation in to language learning strategy use and gender among Iranian undergraduate language learners. World science journal, 11(10), 1236-1247.

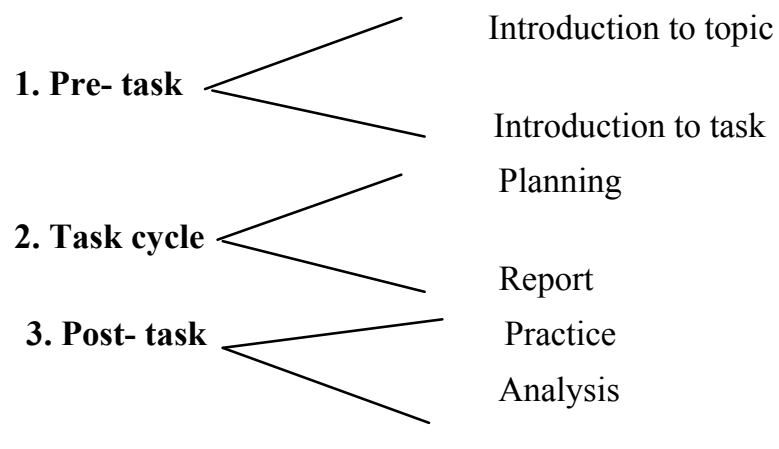

Figure 1. Three phases of applying tasks based on Willis, 1996

\section{Appendix A}

Task-based technical vocabulary teaching in the experimental group

\section{Lesson plan 1}

Topic: Modern Persian Literature

The sample lesson presented in this study belonged to lesson 1: Modern Persian literature. One of the objectives of this unit was to teach the students the technical vocabularies related to the topic in English using the Task-based approach. This lesson contains the pre-task, the task and the post-task phases.

\section{Pre-task}

1. In pre-task phase in order to activate students' schemata the teacher asks questions based on the topic of the reading passage. For example:

- Who can talk about the history of literary tradition?

- Can anyone name some of the famous poets of that time?

- What was the style of traditional poets?

2. Look at the text and try to guess the meaning of following words. Don't worry if you do not understand them. Context will help you to understand the meaning of the word.

The impact of western civilization, which began to affect life in Iran in the course of the $19^{\text {th }}$ century, did not leave its solid literary tradition untouched.

3. Cooperative dictionary use: A group work based on trying to work out definitions of words. Students go through the new words in pairs and have dictionaries at their disposal to check meaning. 


\section{During tasks}

1. Negotiation of meaning: Divide the class in to A and B groups of between 5 students per group. They sit facing each other. Each group has the word with definitions; they try to ask each other.

A asks: what is the meaning of literary tradition?

B replies: literary beliefs, customs, and styles

A asks: what is the meaning of poetical expression?

B replies: the way a poet uses to show his feelings, opinions

2. Information-gap task: Student A would have the vocabulary words written on strips of paper and student B would have the definitions of those words. Working together, they pair words and definitions to learn new vocabulary.

Student A
Adaptability
Wage
Genuine

$$
\begin{gathered}
\text { student B } \\
\text { The ability to adjust } \\
\text { To begin and carry on a war } \\
\text { original, real }
\end{gathered}
$$

3. The teacher writes three new vocabularies on the board and then describes the meaning of one of them; students in group should guess which word is described and say aloud the correct one.

4. Guessing: What is it? After you hear the teacher's description, try to figure out what is described and write down on the paper. Then the teacher asks groups to check the correct answer.

For example: Person acting as one's substitute or representative (deputy)

5. Matching: students work in groups. In the blank they should write the correct letter to match items on the right colum
1. Amateur .......
2. Nationalism......
3. Prosody......
4. Court.....
5. Prose......
6. Adaptability.....

a. a very skilled person

b. the roles of pattern and sound in poetry

c. the ability to change so as to be suitable

d. an artist who is not paid for his art

e. love for one's own country

f. poetical expression

g. the official home of a king or queen

h. written language in its usual form

\section{Post-task}

1. Read the text again and find the vocabularies which seem problematic to you. Then ask teacher for help.

2. The teacher considers students performance on different types of tasks and finds problematic areas to be worked or practiced.

3. Fill in the blanks.

1. The rules of pattern and sound in poetry are

2. Although he's only an/a ............ , he's a first class player.

\section{Lines, structure, prosody, constitution, intellectual, attitude, Amateur, waged, vicissitude, poem}

3. Britain is governed with unwritten

4. A few of Iran's participate in Persian literature Conference.

5. A battle was against the enemy.

6. Literature has important role in political and social of nation. 
7. The ancient. of Persian literature was changed in the course of $19^{\text {th }}$ century.

8. The writer composes

9. Western civilization caused fundamental change in the of the poet toward his art.

10. In court poetry, most of poet works on traditional

4. Fill the appropriate word in each column. poetry, wage, vicissitude, innovatively, remarkable, constitution, poetically, western, attack, genuine, evolve, entirely,

\begin{tabular}{llll}
\hline verb & Noun & adverb & adjective
\end{tabular}

